\title{
Tissue microRNAs as predictive markers for gastric cancer patients undergoing palliative chemotherapy
}

\author{
DAVID SMID ${ }^{1}$, VLASTIMIL KULDA ${ }^{2}$, KRISTYNA SRBECKA ${ }^{2}$, DASA KUBACKOVA ${ }^{1}$, \\ JAN DOLEZAL $^{1}$, ONDREJ DAUM ${ }^{3}$, RADEK KUCERA $^{4}$, ONDREJ TOPOLCAN ${ }^{4}$, \\ VLADISLAV TRESKA ${ }^{1}$, TOMAS SKALICKY ${ }^{1}$ and MARTIN PESTA ${ }^{5,6}$ \\ ${ }^{1}$ Department of Surgery, Faculty of Medicine in Pilsen, Charles University in Prague, Pilsen 30460; ${ }^{2}$ Department of Medical \\ Chemistry and Biochemistry, Faculty of Medicine in Pilsen, Charles University in Prague, Pilsen 30166; \\ ${ }^{3}$ Department of Pathology, Faculty of Medicine in Pilsen, Charles University in Prague, Pilsen 30599; \\ ${ }^{4}$ Department of Nuclear Medicine-Immunoanalytic Laboratory, University Hospital in Pilsen, Pilsen 30599; \\ ${ }^{5}$ Department of Biology, Faculty of Medicine in Pilsen, and ${ }^{6}$ Biomedical Centre, Faculty of \\ Medicine in Pilsen, Charles University in Prague, Pilsen 32600, Czech Republic
}

Received January 25, 2016; Accepted March 9, 2016

DOI: $10.3892 /$ ijo.2016.3484

\begin{abstract}
MicroRNAs have the potential to become valuable predictive markers for gastric cancer. Samples of biopsy tissue, routinely taken from gastric cancer patients undergoing palliative chemotherapy, constitute suitable material for microRNA profiling with the aim of predicting the effect of chemotherapy. Our study group consisted of 54 patients, all of whom underwent palliative chemotherapy based on 5-fluorouracil (5-FU) or 5-FU in combination with platinum derivatives between 2000 and 2013. The expression of 29 selected microRNAs and genes BRCA1, ERCC1, RRM1 and TS, in gastric cancer tissue macrodissected from FFPE tissue samples, was measured by quantitative RT-PCR. The relationship between gene expression levels and time to progression (TTP) and overall survival (OS) was analysed. From the set of the 29 microRNAs of interest, we found high expression of miR-150, miR-342-3p, miR-181b, miR-221, miR-224 and low levels of miR-520h relate to shorter TTP. High levels of miR-150, miR-192, miR-224, miR-375 and miR-342-3p related to shorter OS. In routinely available FFPE tissue samples, we found 6 miRNAs with a relation to TTP, which may serve as predictors of the effectiveness of palliative treatment in gastric cancer patients. These miRNAs could also help in deciding whether to indicate palliative chemotherapy.
\end{abstract}

Correspondence to: Dr Martin Pesta, Department of Biology, Faculty of Medicine in Pilsen, Charles University in Prague, Alej Svobody 76, Pilsen 32600, Czech Republic

E-mail: martin.pesta@lfp.cuni.cz

Key words: gastric cancer, microRNA, formalin-fixed paraffinembedded tissue, prognostic markers, predictive markers

\section{Introduction}

Gastric cancer rates as the fourth most common malignancy worldwide and is the third most common cause of death from a malignant disease, after lung and liver cancer (1). Eastern Asia accounts for more than $50 \%$ of cases registered globally. A gradual decrease in the number of cases has been observed in regions such as the United States, Western and Central Europe (2,3).

In 2012, the incidence of gastric cancer in the Czech Republic was 14.6 cases per 100,000 inhabitants. Most cases are diagnosed in the late stages of the disease and only palliative treatment remains possible. Chemotherapy is often embarked upon as part of palliative treatment and most patients receive the same medications, overall survival varies greatly from patient to patient, however. One possible cause of this variability could be the gene expression changes occurring in cancer tissue, which may alter the effect of cytostatics. Evaluating the expression of specific genes including genes for microRNA (miRNA) could help single out chemotherapy efficacy predictors in gastric cancer patients undergoing palliative treatment $(4,5)$. By identifying patients with chemoresistant tumors, we hope to spare them the strain of inefficient chemotherapy.

The tissue samples were the same as those used by the pathologists when making the diagnoses, to measure the levels of chemotherapy response predictors. The use of efficacy predictors makes up an important part of the development of new targeted therapy drugs and their introduction into clinical practice; this is no less the case for conventional chemotherapeutics.

The ability of cancer cells to overcome the effects of chemotherapy by changing the expression of repair genes, enzymes partaking in nucleic acid metabolism and genes involved in apoptosis limits the success of chemotherapy. Eukaryotic cells react to DNA damage by activating repair mechanisms with these key functions: DNA damage detection, stopping replication of damaged DNA, repair of damaged area if possible 
Table I. Primer sequences for quantitative reverse transcription polymerase chain reaction (qRT-PCR) with the probes of Universal Probe Library.

\begin{tabular}{llll} 
Symbol Gene name $\quad$ Function of the product of this gene & Primer sequence 5'-3' & probe \\
\hline
\end{tabular}

Reference genes

GAPDH Glyceraldehyde-3phosphate dehydrogenase

HPRT Hypoxanthine guanine phosphoribosyltransferase

Predictors of treatment response

ERCC1 Excision repair crosscomplementary group 1

RRM1 Ribonucleotide reductase subunit M1

BRCA1 Breast cancer 1

TS

Thymidylate synthase
Enzyme of glycolysis.

Purine salvage pathway.

Nucleotide excision repair

pathway, catalyzes the

5 ' incision in the process

of excising the DNA lesion.

Studied as a predictor of

platinum chemotherapy drugs.

Subunit of an enzyme

essential for the production

of deoxyribonucleotides

needed for DNA synthesis.

Studied as a predictor

of vinorelbine.

Protein involved in DNA

repair of double-stranded breaks,

and recombination. Studied

as a predictor of platinum drugs.

Methylation of deoxyuridylate

to deoxythymidylate needed

for DNA synthesis. Studied as a

predictor of 5-fluorouracil and

folate antimetabolites.
AGCCACATCGCTCAGACAC

60 GCCCAATACGACCAAATCC

TGACCTTGATTTATTTTGCATACC CGAGCAAGACGTTCAGTCCT

GAAATTTGTGATACCCCTCGAC

GATCGGAATAAGGGCTTGG

AAGCACCCTGACTATGCTATCC

71

GTTATAGAGGTCTTCCATCACATCAC

TTGTTGATGTGGAGGAGCAA

11

CAGATTCCAGGTAAGGGGTTC

CCCAGTTTATGGCTTCCAGT

GCAGTTGGTCAACTCCCTGT

43 or else the induction of apoptosis. Nucleotide excision repair (NER), base excision repair (BER), mismatch repair (MMR) and homologous recombination repair (HRR) belong to the most important repair mechanisms of eukaryotic cells $(6,7)$. Damage to these mechanisms means that mutations are passed on to the next cell generation. Impaired function of DNA repair mechanisms is thus linked to both ageing and cancerogenesis. However, increased activity of these mechanisms can hinder chemotherapy by forestalling further effective damage to DNA and thereby preventing the activation of apoptosis in proliferating tumor cells (8).

Cisplatin acts cytotoxically by creating adducts, which participate in crosslinking DNA, and in so doing activates programmed cell death. Decrease in the scale of damage to DNA, whether as a result of fewer adducts being created (in lower drug dosage, for instance) or because of their repair, can lead to a decrease of efficacy of this chemotherapeutic substance (9).

5-Fluorouracil (5-FU) is one of the most commonly used chemotherapeutics in gastric cancer treatment regimens (10).
The primary site of action for 5-FU is thymidylate synthase (TS), an essential enzyme in de novo biosynthetic pathway of deoxythymidylate (dTMP). Thymidylate synthase catalyzes the reductive methylation of dUMP (deoxyuridine-5-prime monophosphate or deoxyuridylate) to dTMP (deoxythymidine-5-prime monophosphate or deoxythymidylate) using 5,10-methylenetetrahydrofolate as a cofactor. Maintaining a dTMP pool is crucial for DNA replication and repair.

We measured the levels of mRNA of the excision repair cross-complementary group 1 gene (ERCC1), ribonucleotide reductase subunit M1 gene (RRM1), breast cancer 1 gene (BRCA1) and TS, all of which participate in repair to damaged DNA. We determined their relationship to time to progression (TTP), using the definition of progression according to RECIST (response evaluation criteria in solid tumours) criteria (11), and overall survival (OS). Table I lists the basic characteristics of the genes of interest.

In addition to genes whose products are directly involved in DNA repair and nucleic acid metabolism, we also focused on gene products that seem to affect the expression of genes 
involved in the above mentioned processes. MicroRNAs (also known as miRNAs or miRs), small non-coding RNA molecules 18-23 nucleotides in length, make up an immense group of regulatory molecules involved in carcinogenesis. The human genome may encode over 2,500 miRNAs, which may target $\sim 60 \%$ of mammalian genes and are abundant in many human cell types (see miRNA database available online at www.mirbase.org). MicroRNAs participate in the post-transcriptional regulation of gene expression controlling development and maintain diverse cellular processes including proliferation, apoptosis, differentiation, motility and morphogenesis.

The effect of microRNA regulatory networks in cancer tissue can be oncogenic (by targeting tumor suppressor genes) or tumor-suppressive (by post-transcriptional repression of oncogenes) (12). However, the final effect of any particular miRNA is time and tissue dependent (13).

Many studies have described changes in expression of miRNAs and their involvement in carcinogenesis, tumor progression, invasion, metastasis and the effects of treatment in gastric cancer tissue. MicroRNAs may become valuable diagnostic markers and therapeutic targets for gastric cancer (14). Based on our research of published literature, we chose 29 miRNAs, which have a potential role in carcinogenesis or drug metabolism and therefore could be expected to influence the efficacy of treatment. A list of the main characteristics of miRNAs of interest is shown in Table II.

\section{Materials and methods}

Ethics statement. The present study was approved by the ethics committee of the University Hospital in Pilsen (decision from 11.7.2012 to the grant NT14227). Anonymised data were used to conduct this study.

Patients. This was a retrospective study. The patients were treated at the Complex Oncology Center of the University Hospital in Pilsen between 1st January 2000 and 30th June 2013. The inclusion criteria of this study were: patients with gastric cancer, with no gastric resection treatment, who underwent palliative chemotherapy only. We evaluated nearly 1,300 cases, all of which were treated at the Complex Oncology Center, but our inclusion criteria meant only 54 cases could be used in the present study. Stage of disease was determined using the TNM (tumor-node-metastasis) system of the International Union Against Cancer (IUCC, 7th edition) (15). All patients were in the fourth stage of the disease. Each diagnosis of gastric cancer was verified by a pathologist.

Tissue samples. Biopsy tissue samples, gathered, using endoscopy, from gastric cancer patients for diagnostic purposes prior to chemotherapy, were processed by standard laboratory techniques at the Institute of Pathology of the University Hospital in Pilsen, Czech Republic. FFPE tissue samples were stored at room temperature until use. Paraffin sections (4- $\mu \mathrm{m}$ thick) were stained with hematoxylin and eosin (H\&E), microscopically verified by pathologists and examined in order to identify sites with cancer cells and sites of adjacent non-cancerous epithelial tissue suitable for macrodissection. Areas selected for expression analysis were highlighted manually.
RNA isolation. Total RNA (including microRNA) was extracted from $10-\mu \mathrm{m}$ FFPE sections following macrodissection of tumor tissue and adjacent non-cancerous tissue using the miRNeasy FFPE kit (Qiagen, Hilden, Germany) as we previously described (16). The paired samples (tumor and adjacent non-cancerous tissue) were only available from 18 patients. The $10-\mu \mathrm{m}$ sections corresponded to H\&E representatives, on the areas highlighted for macrodissection.

Quantitative estimation of protein coding gene expression. Quantitative estimation of mRNA of selected genes (BRCA 1, ERCC1, RRM1 and TS) was performed by a realtime RT-PCR method with Universal Probe Library (UPL) probes (Roche, Mannheim, Germany). Reverse transcription was performed on $50 \mathrm{ng}$ of total RNA with Superscript III reverse transcriptase (Life Technologies, Carlsbad, CA, USA) and random hexamers as primers. The sequences of primers and corresponding UPL probes generated by ProbeFinder software (Roche) are shown in Table I. The primers were synthesized by East Port Praha (Prague, Czech Republic). The quantitative estimation was performed in technical duplicates on Stratagene Mx3005P apparatus (Agilent Technologies, Santa Clara, CA, USA). The $20-\mu 1$ PCR reactions included $1.0 \mu \mathrm{l}$ of RT product, FastStart TaqMan Probe Master (Roche), $2.5 \mu \mathrm{l}$ of each primer and $2.5 \mu \mathrm{l}$ of UPL probe. The reactions were incubated in 96 -well plates at $95^{\circ} \mathrm{C}$ for $10 \mathrm{~min}$ and then followed by 48 cycles of $95^{\circ} \mathrm{C}$ for $10 \mathrm{sec}$ and $60^{\circ} \mathrm{C}$ for $30 \mathrm{sec}$.

All the samples were also assessed for the expression of reference genes GAPDH (glyceraldehyde-3-phosphate dehydrogenase) and HPRT (hypoxanthine-guanine phosphoribosyltransferase). Due to generally low HPRT expression and small yield of RNA isolated from FFPE tissue (small tissue samples), we were unable to measure the expression of HPRT in all of our samples. Therefore, we did not use HPRT data for normalization along with GAPDH and total RNA.

Quantitative estimation of microRNA expression. A quantitative estimation of selected microRNAs (Table II) was performed by a RT real-time PCR method using TaqMan ${ }^{\circledR}$ MicroRNA assays (Applied Biosystems, Foster City, CA, USA) in technical duplicates on Stratagene Mx3005P apparatus (Agilent Technologies). A two-step protocol requires reverse transcription with a miRNA-specific primer, followed by a real-time PCR with TaqMan ${ }^{\circledR}$ probes. The assays target only mature miRNAs, not their precursors. We used RNU6B (U6snRNA) as a normalizer.

Processing of real-time PCR data. Samples were assessed in technical duplicates. The $\mathrm{Ct}$ values were corrected using calibrators to eliminate differences between the individual runs of the real-time PCR apparatus. In cases where there was a discrepancy between the results obtained from both technical duplicates, the sample assessment was repeated. The results are presented as normalized values as a ratio of the number of copies of the given gene to that of the reference gene. To obtain gene expression data we used the $\Delta \Delta \mathrm{Ct}$ approach $\left(2^{-\Delta \Delta \mathrm{Ct}}\right.$ algorithm).

Statistical analysis. The statistical analysis was performed using SAS 9.3 software (SAS, Institute Inc., Cary, NC, USA). 
Table II. The analysed microRNAs and their involvement in the cancer process.

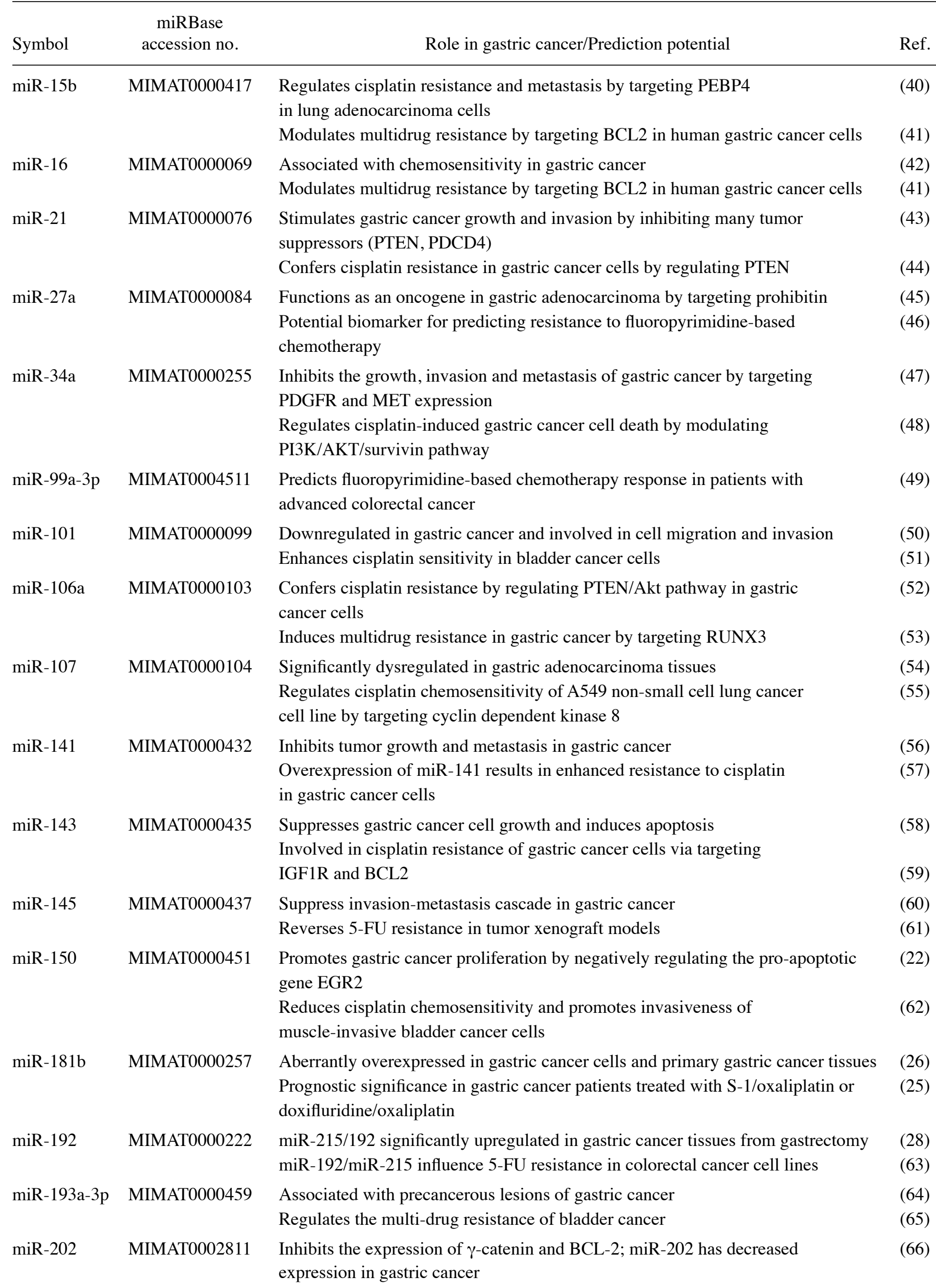


Table II. Continued.

miRBase

Symbol accession no.

Role in gastric cancer/Prediction potential

Ref.

\begin{tabular}{|c|c|c|}
\hline miR-206 & MIMAT0000462 & $\begin{array}{l}\text { Suppresses gastric cancer cell growth and metastasis } \\
\text { Inhibition of gastric cancer progression through the c-Met pathway }\end{array}$ \\
\hline $\operatorname{miR}-211$ & MIMAT0000268 & $\begin{array}{l}\text { Associated with gastric cancers as potential biomarkers for gastric cancer } \\
\text { diagnosis and treatment } \\
\text { Downregulation of ribonucleotide reductase }\end{array}$ \\
\hline $\operatorname{miR}-218$ & MIMAT0000275 & $\begin{array}{l}\text { Inhibits invasion and metastasis of gastric cancer } \\
\text { Regulates cisplatin chemosensitivity in breast cancer by targeting BRCA1 }\end{array}$ \\
\hline $\operatorname{miR}-221$ & MIMAT0000278 & miR-221/222 are encoded in tandem and they have the same seed sequence; \\
\hline $\operatorname{miR}-222$ & MIMAT0000279 & $\begin{array}{l}\text { miR-221 and miR-222 regulate gastric carcinoma cell proliferation and } \\
\text { radioresistance by targeting PTEN }\end{array}$ \\
\hline $\operatorname{miR}-224$ & MIMAT0000281 & $\begin{array}{l}\text { Promotes chemoresistance of lung adenocarcinoma cells to cisplatin } \\
5-\mathrm{FU} \text { chemosensitivity is significantly increased in miR-224 knockdown cells }\end{array}$ \\
\hline $\operatorname{miR}-342-3 p$ & MIMAT0000753 & Upregulation is associated with chemosensitivity in gastric cancer \\
\hline $\operatorname{miR}-372-3 p$ & MIMAT0000724 & $\begin{array}{l}\text { Maintains oncogene characteristics by targeting TNFAIP1 and affects } \\
\mathrm{NF}-\kappa \mathrm{B} \text { signaling in human gastric carcinoma cells }\end{array}$ \\
\hline $\operatorname{miR}-375$ & MIMAT0000728 & $\begin{array}{l}\text { Downregulated in gastric cancer, inhibits cell migration and invasion by } \\
\text { targeting JAK2 } \\
\text { Predictive for response for non-small cell lung cancer treated with } \\
\text { cisplatin-vinorelbine A }\end{array}$ \\
\hline $\operatorname{miR}-509-3 p$ & MIMAT0002881 & Inhibits cell proliferation and migration by targeting CDK2, Rac1, and PIK $3 \mathrm{C} 2 \mathrm{~A}$ \\
\hline $\operatorname{miR}-575$ & MIMAT0003240 & Significantly upregulated in gastric cancer \\
\hline $\operatorname{miR}-520 \mathrm{~h}$ & MIMAT0002867 & $\begin{array}{l}\text { Downregulates histone deacetylase } 1 \text { and so contributes to the chemotherapeutic } \\
\text { effect of doxorubicin } \\
\text { Controls ABCG2 level and thereby anticancer drug response }\end{array}$ \\
\hline
\end{tabular}

The statistical results were calculated by a Wilcoxon nonparametric two sample test. For the maximum hazard ratio (OS, TTP) the Cox regression hazard model was used. After finding an 'optimal cut off' given by the lowest P-value of logrank test for the examined markers, the Kaplan-Meier survival distribution functions determined by the 'optimal cut off' in given groups and subgroups were generated.

\section{Results}

Prior to our analysis of the relationship between gene expression and TTP and OS, we compared gene expression in cancer and adjacent non-cancer epithelial gastric tissue. We found the expression of miR-221 in cancer tissue to be significantly higher, while the expression of miR-202 and miR-509 proved to be lower compared to healthy tissue (P-value 0.013, 0.011 and 0.018 , respectively). However, when drawing conclusions from this analysis, we have to take into account the low number of paired samples, caused by the lack of non-cancerous tissue in some of the FFPE samples.

The Cox regression hazard model was used to determine the relation of marker level to OS or TTP. Results for all markers are summarized in Table III. From the set of the 29 microRNAs of interest, we found high expression levels of miR-150, miR 342-3p, miR-181b, miR-221, miR-224 and low levels of miR-520h related to shorter TTP. High levels of miR-150, miR-192, miR-224, miR-375 and miR-342-3p related to shorter OS. For markers with statistically significant results, optimal cut off values were chosen and Kaplan-Meier survival distribution functions for OS and TPP were generated.

The treatment regimen of all patients included 5-FU. We noted a definite correlation between high levels of miR-150 and miR-342-p in cancerous tissue and shorter TTP as well as OS. High expression of miR-224, however, only proved to have a relation to shorter OS (Table IV and Fig. 1).

In the subgroup of patients receiving 5-FU as the only treatment, we recorded a relation between high levels of miR-181b and shorter TTP and between high levels of miR-150, miR-192 and miR-342-p and shorter OS. In the subgroup treated with both 5-FU and cisplatin, we noted that high levels of miR-221, miR-224 and low levels of miR-520 related to shorter TTP and high levels of miR-221, miR-224 and miR-375 to shorter OS (Table V and Fig. 2).

\section{Discussion}

The present study focused on patients in advanced stages of gastric cancer. Therefore, these patients could not have the 
Table III. Relation between level of given marker and TTP or OS (Cox regresion hazard model).

\begin{tabular}{|c|c|c|c|c|c|c|c|c|c|c|c|c|}
\hline \multirow[b]{3}{*}{ Marker } & \multicolumn{4}{|c|}{ All patients } & \multicolumn{4}{|c|}{ 5-FU alone } & \multicolumn{4}{|c|}{ 5-FU/cisplatin } \\
\hline & \multicolumn{2}{|c|}{ OS } & \multicolumn{2}{|c|}{ TTP } & \multicolumn{2}{|c|}{ OS } & \multicolumn{2}{|c|}{ TTP } & \multicolumn{2}{|c|}{ OS } & \multicolumn{2}{|c|}{ TTP } \\
\hline & P-value & HR & P-value & HR & P-value & HR & P-value & HR & $\mathrm{P}$-value & HR & P-value & HR \\
\hline ERCC1 & 0.9896 & 1.000 & 0.6452 & 0.547 & 0.2203 & 1.083 & 0.1464 & 1.103 & 0.2740 & $*$ & 0.0679 & * \\
\hline RRM1 & 0.8615 & * & 0.8486 & * & 0.7395 & $*$ & 0.7137 & $*$ & 0.4886 & * & 0.1703 & * \\
\hline BRCA1 & 0.1658 & 17.340 & 0.4511 & 4.261 & 0.1881 & $*$ & 0.2095 & $*$ & 0.9996 & $*$ & 0.4076 & $*$ \\
\hline TS & 0.3422 & $*$ & 0.4118 & $*$ & 0.0524 & 0.985 & 0.4693 & $*$ & 0.5148 & $*$ & 0.3000 & $*$ \\
\hline miR-15b & 0.3772 & 1.247 & 0.5953 & 1.199 & 0.2288 & 2.749 & 0.7050 & 1.380 & 0.2717 & 1.468 & 0.4768 & 1.297 \\
\hline miR-16 & 0.4178 & 1.003 & 0.7514 & 1.001 & 0.4816 & 1.003 & 0.6070 & 1.002 & 0.1216 & 1.053 & 0.1344 & 1.050 \\
\hline miR-21 & 0.5122 & 1.001 & 0.7040 & 1.001 & 0.5362 & 1.001 & 0.5916 & 1.001 & 0.4965 & 1.007 & 0.3586 & 1.011 \\
\hline miR-27a & 0.1592 & 1.105 & 0.3201 & 1.072 & 0.1169 & 1.315 & 0.4536 & 1.141 & 0.1402 & 1.387 & 0.0716 & 1.568 \\
\hline miR-34a & 0.5279 & 1.014 & 0.8185 & 1.005 & 0.5976 & 1.019 & 0.8735 & 1.006 & 0.0567 & 1.536 & 0.0806 & 1.626 \\
\hline miR-99a-3p & 0.1951 & $*$ & 0.7863 & 2.705 & 0.4441 & $*$ & 0.7846 & 5.008 & 0.4712 & $*$ & 0.7964 & 5.091 \\
\hline miR-101 & 0.3734 & 4.040 & 0.6222 & 2.142 & 0.3617 & 4.703 & 0.6637 & 2.110 & 0.9744 & 1.299 & 0.0966 & $*$ \\
\hline miR-106a & 0.4283 & 1.034 & 0.5075 & 1.028 & 0.4467 & 1.038 & 0.6843 & 1.022 & 0.4066 & 1.106 & 0.7731 & 1.039 \\
\hline miR-107 & 0.4980 & 1.829 & 0.6703 & 1.438 & 0.6056 & 1.713 & 0.9425 & 0.928 & 0.1013 & $*$ & 0.1739 & $*$ \\
\hline miR-141 & 0.2236 & 1.241 & 0.1042 & 1.295 & 0.0646 & 1.946 & 0.1968 & 1.609 & 0.7076 & 1.134 & 0.2205 & 1.460 \\
\hline miR-143 & 0.5144 & 1.002 & 0.8042 & 1.001 & 0.5847 & 1.002 & 0.6593 & 1.002 & 0.0619 & 1.395 & 0.0537 & 2.322 \\
\hline miR-145 & 0.4063 & 1.001 & 0.8176 & 1.000 & 0.5373 & 1.001 & 0.6376 & 1.001 & 0.0727 & 1.057 & 0.1059 & 1.121 \\
\hline miR-150 & 0.0494 & 1.004 & 0.0056 & 1.006 & 0.0438 & 1.039 & 0.0743 & 1.034 & 0.1311 & 1.004 & 0.2351 & 1.046 \\
\hline miR-181b & 0.1406 & 1.061 & 0.0882 & 1.063 & 0.0564 & 1.130 & $\mathbf{0 . 0 3 3 3}$ & 1.777 & 0.3327 & 1.185 & 0.2270 & 1.082 \\
\hline miR-192 & 0.7227 & 1.011 & 0.8569 & 1.006 & 0.0233 & 1.200 & 0.3684 & 1.080 & 0.8814 & 0.992 & 0.5269 & 0.959 \\
\hline miR-193a-3p & 0.2323 & 4.798 & 0.7265 & 1.577 & 0.2401 & 7.129 & 0.5706 & 2.464 & 0.3158 & $*$ & 0.0606 & $*$ \\
\hline miR-202 & 0.3803 & 7.022 & 0.6739 & 0.320 & 0.4932 & 6.787 & 0.6010 & 4.384 & 0.1694 & * & 0.0946 & * \\
\hline miR-206 & 0.0594 & $*$ & 0.4452 & $*$ & 0.1810 & $*$ & 0.2963 & $*$ & 0.2441 & $*$ & 0.1440 & $*$ \\
\hline miR-211 & 0.1548 & $*$ & 0.2151 & $*$ & 0.1155 & $*$ & 0.3240 & $*$ & 0.5506 & $*$ & 0.4309 & $*$ \\
\hline miR-218 & 0.0639 & $*$ & 0.6789 & 2.981 & 0.4176 & $*$ & 0.0687 & $*$ & 0.0961 & $*$ & 0.0847 & $*$ \\
\hline miR-221 & 0.1934 & 1.051 & 0.3627 & 1.034 & 0.6144 & 1.032 & 0.7147 & 1.023 & 0.0160 & 2.438 & 0.0371 & 2.099 \\
\hline miR-222 & 0.5086 & 1.001 & 0.6742 & 1.000 & 0.5679 & 1.001 & 0.6445 & 1.001 & 0.2627 & 1.012 & 0.2698 & 1.012 \\
\hline miR-224 & 0.0175 & 7.609 & 0.2724 & 2.620 & 0.1441 & 4.532 & 0.3603 & 2.602 & 0.0283 & 322.120 & 0.0367 & 436.694 \\
\hline miR-342-3p & 0.0286 & 1.261 & 0.0144 & 1.383 & 0.0443 & 2.516 & 0.1531 & 2.077 & 0.1383 & 1.272 & 0.1641 & 1.692 \\
\hline miR-372-3p & 0.6113 & 1.000 & 0.1651 & 7.159 & 0.5731 & $*$ & 0.5128 & $*$ & 0.2737 & 6.344 & 0.2863 & 6.080 \\
\hline miR-375 & 0.1968 & $*$ & 0.9422 & 1.000 & 0.4974 & 1.001 & 0.9324 & 1.011 & 0.0427 & 1.362 & 0.8672 & 1.000 \\
\hline miR-509-3p & 0.2446 & 3.507 & 0.6196 & $*$ & 0.6909 & $*$ & 0.5540 & $*$ & 0.1246 & $*$ & 0.1607 & $*$ \\
\hline miR-575 & 0.1999 & $*$ & 0.4849 & $*$ & 0.4778 & $*$ & 0.5664 & $*$ & 0.6211 & $*$ & 0.5531 & $*$ \\
\hline miR-520h & 0.1712 & * & 0.1190 & * & 0.3799 & $*$ & 0.2106 & $*$ & 0.0977 & * & 0.0483 & 0.584 \\
\hline
\end{tabular}

*Clinically unrealistic hazard ratio (HR) values due to the coincidence of extreme marker level and extreme time to event in some cases.

tumors surgically removed and underwent palliative treatment only. The main clinical concern in such cases is deciding which chemotherapeutic regimen is indicated. The question was whether we could predict the effect of chemotherapy and thereby determine, if the aggressive chemotherapeutic treatment, which inevitably decreases quality of life, would prolong survival. If a low effect of treatment is predicted, it would be appropriate to offer to those patients inclusion in new ongoing studies.
In our laboratory assessment we used tissue samples taken gastroscopically for routine diagnostic purposes and macrodissected a sample of cancerous tissue, verified by a pathologist from FFPE sections, to analyse the expression of genes influencing the effects of therapy. This approach can be easily translated into clinical practice. We conducted expression analysis from a large number of tumor cells. Cancerous tissue is heterogeneous by nature, and originates in the process of clonal evolution, and therefore examining the collective 
Table IV. Relation between level of given microRNA and TTP or OS (Kaplan-Meier estimation).

\begin{tabular}{|c|c|c|c|c|c|c|c|}
\hline \multirow[b]{2}{*}{ Marker } & \multirow[b]{2}{*}{ No. of patients } & \multirow[b]{2}{*}{ Cut-off } & \multicolumn{2}{|c|}{ Patients below cut-off } & \multicolumn{2}{|c|}{ Patients above cut-off } & \multirow[b]{2}{*}{ P-value } \\
\hline & & & $\mathrm{N}$ & Median (days) & $\mathrm{N}$ & Median (days) & \\
\hline \multicolumn{8}{|c|}{ Time to progression (TTP) } \\
\hline miR-150 & 40 & $\begin{array}{l}43 \\
6.7\end{array}$ & 23 & $\begin{array}{l}113 \\
138\end{array}$ & 17 & $\begin{array}{l}26 \\
90\end{array}$ & 0.0232 \\
\hline \multirow[t]{2}{*}{ miR-342-3p } & 42 & 2.7 & 40 & 106.5 & 1 & 12 & 0.0006 \\
\hline & & 0.6 & 31 & 113 & 10 & 66 & 0.0997 \\
\hline \multicolumn{8}{|c|}{ Overall survival (OS) } \\
\hline \multirow[t]{2}{*}{ miR-150 } & 41 & 45 & 38 & 215 & 3 & 69 & 0.0020 \\
\hline & & 6 & 21 & 424 & 20 & 172.5 & 0.0145 \\
\hline miR-342-3p & 42 & 0.45 & 25 & 304 & 17 & 170 & 0.0319 \\
\hline miR-224 & 41 & 0.048 & 15 & 494 & 26 & 175 & 0.0090 \\
\hline
\end{tabular}
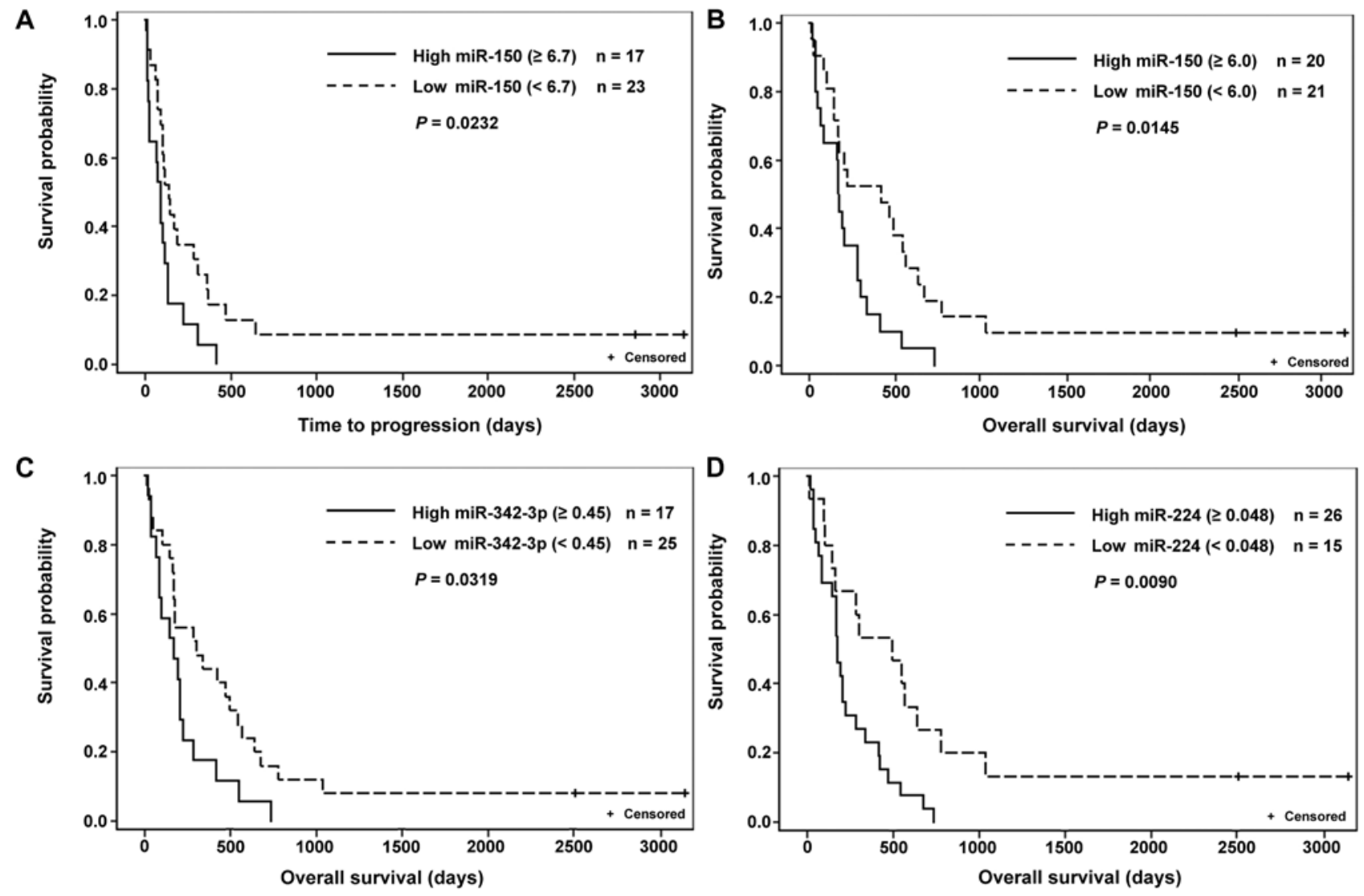

Figure 1. Relation of microRNA expression to time to progression (TTP)/overall survival (OS) in all gastric cancer patients (Kaplan-Meier curves).

changes in expression of a variety of cancer cell types (gathered by macrodissection) provides a more complex insight regarding prognosis. We set out to ascertain the prognostic potential of chosen miRNAs, which influence apoptosis and cell proliferation and in so doing interact with the mechanism of chemotherapy indicated in the cases we examined. However, we could not leave out monitoring protein coding genes frequently investigated as possible treatment outcome predictors.
Many studies have noted the prognostic value of low ERCC1 expression in gastric cancer patients undergoing chemotherapy; a meta-analysis published in 2015 concluded ERCC1 may be a useful prognostic factor for gastric cancer and furthermore that low mRNA levels of ERCC1 appear to be associated with a significant OS benefit to patients treated with platinum-based chemotherapy (17). However, the predictive value of the ERCC1 gene for survival and response to platinum-based chemotherapy in gastric cancer remains 
Table V. Relation between level of given marker and TTP or OS based on the treatment (Kaplan-Meier estimation).

\begin{tabular}{|c|c|c|c|c|c|c|c|c|}
\hline \multirow[b]{2}{*}{ Marker } & \multirow[b]{2}{*}{ No. of patients } & \multirow[b]{2}{*}{ Cut-off } & \multicolumn{2}{|c|}{$\begin{array}{l}\text { Patients below } \\
\text { cut-off }\end{array}$} & \multicolumn{2}{|c|}{$\begin{array}{l}\text { Patients above } \\
\text { cut-off }\end{array}$} & \multirow[b]{2}{*}{ P-value } & \multirow{2}{*}{$\begin{array}{l}\text { Relation to } \\
\text { OS/TTP }\end{array}$} \\
\hline & & & $\mathrm{N}$ & Median (days) & $\mathrm{N}$ & Median (days) & & \\
\hline \multicolumn{9}{|l|}{$\begin{array}{l}\text { Treatment } \\
\text { 5-fluorouracil }\end{array}$} \\
\hline TS & 14 & 0.008 & 11 & 282 & 3 & 547 & 0.0226 & OS \\
\hline miR-150 & 23 & 6.300 & 12 & 424 & 11 & 170 & 0.0099 & OS \\
\hline miR-181b & 21 & 0.260 & 2 & 13.5 & 19 & 147 & 0.0038 & TTP \\
\hline miR-192 & 24 & 2.300 & 16 & 339 & 8 & 39 & 0.0001 & OS \\
\hline miR-342-3p & 24 & 0.600 & 18 & 282 & 6 & 62.5 & 0.0141 & OS \\
\hline $\begin{array}{l}\text { 5-fluorouracil } \\
\text { miR-221 }\end{array}$ & $\begin{array}{l}10 \\
10\end{array}$ & $\begin{array}{l}0.600 \\
1.500\end{array}$ & $\begin{array}{l}4 \\
4\end{array}$ & $\begin{array}{l}732 \\
262.5\end{array}$ & $\begin{array}{l}6 \\
6\end{array}$ & $\begin{array}{l}129.5 \\
67\end{array}$ & $\begin{array}{l}0.0038 \\
0.0356\end{array}$ & $\begin{array}{l}\text { OS } \\
\text { TTP }\end{array}$ \\
\hline $\operatorname{miR}-224$ & $\begin{array}{l}9 \\
9\end{array}$ & $\begin{array}{l}0.150 \\
0.150\end{array}$ & $\begin{array}{l}5 \\
5\end{array}$ & $\begin{array}{l}684.5 \\
108\end{array}$ & $\begin{array}{l}4 \\
4\end{array}$ & $\begin{array}{l}84 \\
43\end{array}$ & $\begin{array}{l}0.0049 \\
0.0027\end{array}$ & $\begin{array}{l}\text { OS } \\
\text { TTP }\end{array}$ \\
\hline $\mathrm{miR}-375$ & 9 & 26.000 & 5 & 637 & 4 & 76.5 & 0.0027 & OS \\
\hline $\mathrm{miR}-520 \mathrm{~h}$ & 10 & 40.000 & 8 & 88 & 2 & 563.5 & 0.0265 & TTP \\
\hline
\end{tabular}
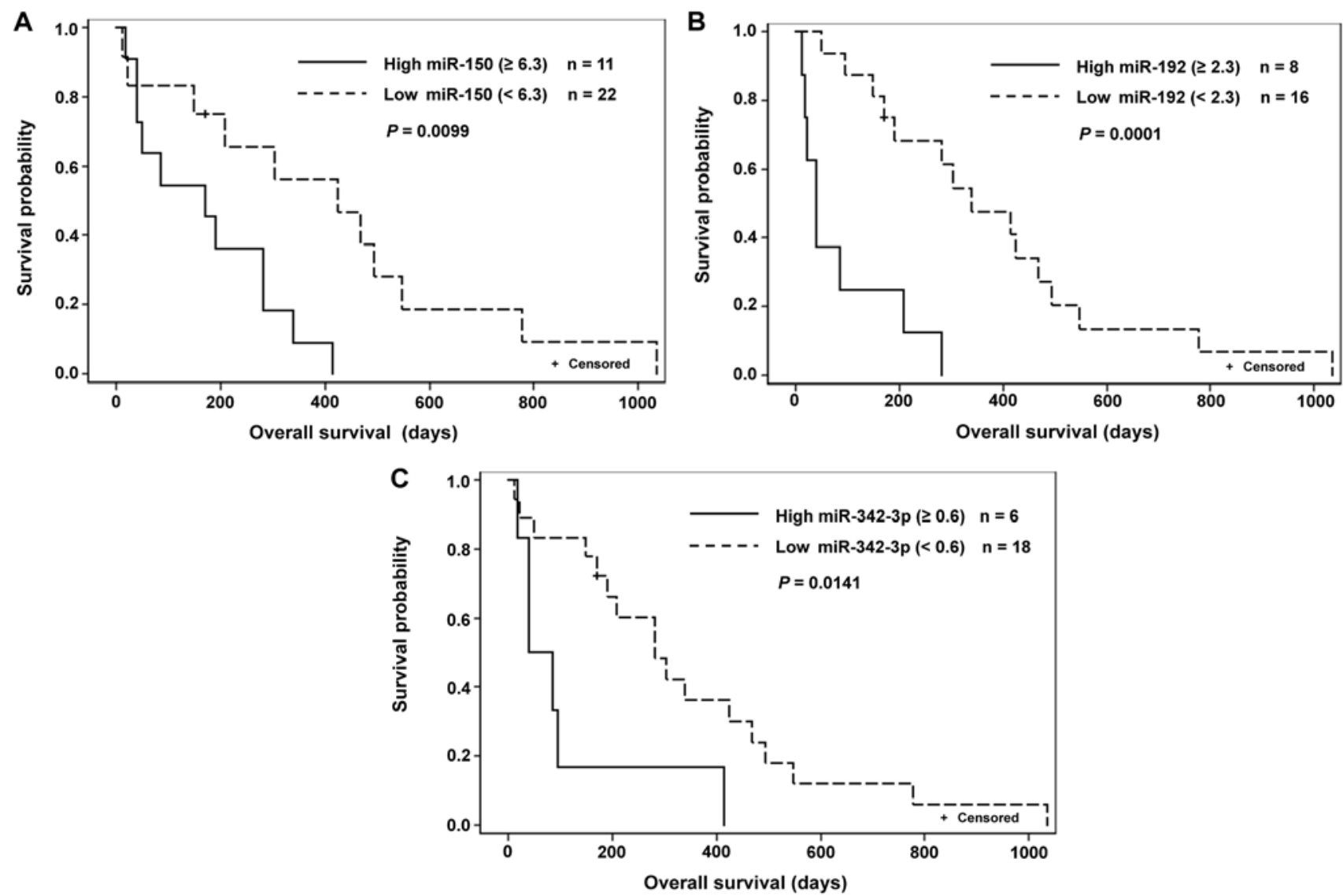

Figure 2. Relation of microRNA expression to overall survival (OS) in the subgroup of gastric cancer patients receiving 5-fluorouracil (5-FU) as the only treatment (Kaplan-Meier curves).

controversial (18). We found no statistically significant relation between the levels of ERCC1 and survival. It is possible our results reflect our test group, as in all cases we examined 5-FU was part of the treatment regimen but platinum-based 
chemotherapy was only used in a subgroup, whose analysis was affected by the small number of patients.

The very nature of the TS enzyme makes its expression the most commonly examined in relation to 5-FU chemotherapy. We determined high levels of TS predict longer OS (Table V). Similar results were published by Wei et al (19), who conducted their analysis on a group of patients treated in the same way and also used RT-PCR to assess TS expression. On the other hand, some studies have shown high levels of TS to have the opposite effect (20).

From the set of the 29 microRNAs of interest, we found that high expression levels of miR-150, miR-181b, miR-192, miR-221, miR-224, miR 342-3p, miR-375 and low expression of miR-520h relate to unfavourable outcomes for patients (shorter TTP or OS) Table III.

MicroRNAs have the potential to become accurate, easily measurable biomarkers, with features fortuitous for diagnostic testing methods, such as stability in FFPE tissue, blood and perhaps other bodily fluids (21).

$\mathrm{Wu}$ et al (22) found miR-150 was overexpressed in gastric cancer cell lines and tissue samples and demonstrated overexpression of miR-150 could promote proliferation and growth of cancer cells by targeting the tumor-suppressor EGR2. In undifferentiated gastric cancer, higher miR-150 levels appeared to be associated with shorter postoperative patient survival, however, miR-150 was deemed to be an insufficiently independent prognostic factor in these cases (23). In the study of Chen et al (24), miR-150 showed decreased expression in gastric cancer patients compared to healthy test subjects. In the present study, higher levels of miR-150 showed a relation to shorter TTP and OS (Table IV; Figs. 1A and $\mathrm{B}$ and $2 \mathrm{~A})$.

Compared to normal gastric tissue samples, there is an overexpression of miR-181b in gastric tumors. Lower levels of miR-181b relate to longer OS of patients on regimens based on 5-FU and platinum derivatives (25). Furthermore, overexpression of $\mathrm{miR}-181 \mathrm{~b}$ was found to downregulate the tissue inhibitor of metalloproteinases 3 (TIMP3) (26). Our results hint at the association of higher miR-181b levels to shorter TTP of patients treated with 5-FU (Table V). The results of another study show the ambiguous nature of the effects of certain miRNA; Chen et al (27) observed miR-181b was downregulated in human gastric adenocarcinoma tissue samples compared to adjacent normal gastric tissue and also described how miR-181b could suppress tumor cell proliferation by downregulating the expression of cAMP responsive element binding protein 1 (CREB1).

Our analysis of miR-192 levels showed its high expression related to shorter OS in the group of patients treated with 5-FU (Table V and Fig. 2B). To the best of our knowledge, no other study dealing with the predictive value of miR-192 in gastric cancer patients treated with 5-FU has been published. Xu et al (28) found miR-192 to be upregulated in gastric cancer tissue samples obtained by gastrectomy. The upregulation of both miR-192 and miR-215 was related to clinical characteristic such as lymph node metastases, while the inhibition of miR-215 or miR-192 significantly decreased gastric cancer cell invasion. The results reported by Chen et al (29) demonstrate that elevated circulating miR-192 has the potential to improve the early detection of distant metastases of GC.
Recently published studies show that miR-221 is an oncogenic microRNA involved in several malignancies $(30,31)$. We found higher miR-221 expression in tumor samples in comparison to adjacent noncancerous tissue. This is in accordance with Liu et al (32) who found miR-221 was upregulated in $88 \%$ of gastric cancer tissue samples. Moreover, we observed a relation of high miR-221 expression to shorter TTP and OS in 5-FU monotherapy treated patients (Table V). The influence of miR-221 on the effect of chemotherapy is corroborated by published experiments conducted on the human gastric cancer cell line SGC7901 showing the knockdown of miR-221 inhibited cell growth and invasion and increased the radiosensitivity of the cells (33).

We found higher levels of miR-224 indicate shorter OS (Table IV and Fig. 1D). Mao et al (34) concluded that miR-224 is overexpressed in human gastric cancer cells. Reducing the expression of miR-224 can effectively inhibit growth and promote apoptosis of gastric cancer cells. These results are also supported by the study of Liu et al (35) who investigated the expression of miR-224 in the human gastric cancer cell line SGC-7901. In examining the effects of miR-224 mimics, they observed miR-224 could negatively regulate the expression of Raf-1 kinase inhibitor protein (RKIP). RKIP contributes to the suppression of proliferation and invasion of gastric cells.

We determined higher levels of miR-342-3p correlated to shorter TTP and OS in 5-FU monotherapy treated patients (Table V and Fig. 2C); similar results were described in colorectal cancer. High levels of miR-342-3p were associated with shorter survival time (36). Kim et al (37) screened miRNAs associated with response to chemotherapy using microarrays and found miR-342-p belongs to the miRNAs, whose upregulation is associated with chemosensitivity in gastric cancer.

Our observations of the relation of high miR-375 expression to shorter OS in 5-FU monotherapy treated patients (Table V) could be explained by the findings of Liu et al (38), who showed that miR-375 downregulated p53 expression through an interaction with the 3 ' UTR region of $\mathrm{p} 53$. In addition, they observed the expression of miR-375 desensitized cells to ionizing radiation and etoposide.

We demonstrated that higher levels of miR-520h correlated to longer TTP in 5-FU and cisplatin therapy treated patients (Table V). Shen et al (39) found that miR-520h downregulates histone deacetylase 1 and, thus, contributes to the chemotherapeutic effect of doxorubicin.

Summarizing the aforelisted results, amongst the miRNAs we examined, we found six miRNAs (miR-150, miR-181, miR-221, miR-224, miR-342-p and miR-520h) with a relation to TTP, which could serve as predictors of the effectiveness of treatment. These results merit multifactorial analysis, which we were, however, unable to perform due to the limited number of samples.

In our experience, microRNAs can generally be assessed with more precision and ease than mRNA of coding genes. This is essentially due to the fact that miRNA analysis is less demanding in terms of both quality and quantity of isolated RNA, features problematic in samples of RNA extracted from FFPE tissue. FFPE tissue samples are routinely taken and analysed during standard gastric cancer management and 
that is why we believe microRNAs could become clinically applicable predictors of the effectiveness of palliative treatment in gastric cancer patients.

\section{Acknowledgements}

The study was supported by the grant of Ministry of Health of the Czech republic NT14227 - Determining predictive factors for a therapeutic effect of chemotherapy in patients with stomach cancer (2013-2015, MZ0/NT).

\section{References}

1. Torre LA, Bray F, Siegel RL, Ferlay J, Lortet-Tieulent J and Jemal A: Global cancer statistics, 2012. CA Cancer J Clin 65 87-108, 2015

2. Rahman R, Asombang AW and Ibdah JA: Characteristics of gastric cancer in Asia. World J Gastroenterol 20: 4483-4490, 2014.

3. Coupland VH, Allum W, Blazeby JM, Mendall MA, Hardwick RH, Linklater KM, Møller H and Davies EA: Incidence and survival of oesophageal and gastric cancer in England between 1998 and 2007, a population-based study. BMC Cancer 12: 11, 2012.

4. Cidon EU, Ellis SG, Inam Y, Adeleke S, Zarif S and Geldart T: Molecular targeted agents for gastric cancer: A step forward towards personalized therapy. Cancers (Basel) 5: 64-91, 2013.

5. Wang JL, Hu Y, Kong X, Wang ZH, Chen HY, Xu J and Fang JY: Candidate microRNA biomarkers in human gastric cancer: A systematic review and validation study. PLoS One 8: e73683, 2013.

6. Menon V and Povirk L: Involvement of $\mathrm{p} 53$ in the repair of DNA double strand breaks: Multifaceted roles of p53 in homologous recombination repair (HRR) and non-homologous end joining (NHEJ). Subcell Biochem 85: 321-336, 2014.

7. Melis JPM, van Steeg H and Luijten M: Oxidative DNA damage and nucleotide excision repair. Antioxid Redox Signal 18: 2409-2419, 2013.

8. Tian H, Gao Z, Li H, Zhang B, Wang G, Zhang Q, Pei D and Zheng J: DNA damage response - a double-edged sword in cancer prevention and cancer therapy. Cancer Lett 358: 8-16, 2015.

9. Vasquez KM: Targeting and processing of site-specific DNA interstrand crosslinks. Environ Mol Mutagen 51: 527-539, 2010.

10. Wagner AD, Unverzagt S, Grothe W, Kleber G, Grothey A, Haerting J and Fleig WE: Chemotherapy for advanced gastric cancer. Cochrane Database Syst Rev (3): CD004064, 2010.

11. Eisenhauer EA, Therasse P, Bogaerts J, Schwartz LH, Sargent D, Ford R, Dancey J, Arbuck S, Gwyther S, Mooney M, et al: New response evaluation criteria in solid tumours: Revised RECIST guideline (version 1.1). Eur J Cancer 45: 228-247, 2009.

12. Hagan JP and Croce CM: MicroRNAs in carcinogenesis. Cytogenet Genome Res 118: 252-259, 2007.

13. Suzuki HI, Katsura A, Matsuyama H and Miyazono K: MicroRNA regulons in tumor microenvironment. Oncogene 34: 3085-3094, 2015.

14. Jiang C, Chen X, Alattar M, Wei J and Liu H: MicroRNAs in tumorigenesis, metastasis, diagnosis and prognosis of gastric cancer. Cancer Gene Ther 22: 291-301, 2015.

15. Sobin LH, Gospodarowicz MK and Wittekind Ch: TNM classification of malignant tumours. 7th edition. Wiley-Blackwell, Hoboken, NJ, 2009.

16. Kalfert D, Pesta M, Kulda V, Topolcan O, Ryska A, Celakovsky P Laco J and Ludvikova M: MicroRNA profile in site-specific head and neck squamous cell cancer. Anticancer Res 35: 2455-2463, 2015.

17. Song P, Yin Q, Lu M, Fu BO, Wang B and Zhao Q: Prognostic value of excision repair cross-complementation group 1 expression in gastric cancer: A meta-analysis. Exp Ther Med 9: 1393-1400, 2015.

18. Yao A, Wang Y, Peng X, Ye R, Wang Q, Qi Y and Zhou F: Predictive value of excision repair cross-complementation group 1 expression for platinum-based chemotherapy and survival in gastric cancer: A meta-analysis. J Cancer Res Clin Oncol 140: 2107-2117, 2014.
19. Wei J, Zou Z, Qian X, Ding Y, Xie L, Sanchez JJ, Zhao Y, Feng J, Ling Y, Liu Y, et al: ERCC1 mRNA levels and survival of advanced gastric cancer patients treated with a modified FOLFOX regimen. Br J Cancer 98: 1398-1402, 2008.

20. Hu HB, Kuang L, Zeng XM, Li B, Liu EY and Zhong MZ: Predictive value of thymidylate synthase expression in gastric cancer: A systematic review with meta-analysis. Asian Pac J Cancer Prev 13: 261-267, 2012.

21. Faruq O and Vecchione A: microRNA: Diagnostic Perspective. Front Med (Lausanne) 2: 51, 2015

22. Wu Q, Jin H, Yang Z, Luo G, Lu Y, Li K, Ren G, Su T, Pan Y, Feng B, et al: MiR-150 promotes gastric cancer proliferation by negatively regulating the pro-apoptotic gene EGR2. Biochem Biophys Res Commun 392: 340-345, 2010.

23. Katada T, Ishiguro H, Kuwabara Y, Kimura M, Mitui A, Mori Y, Ogawa R, Harata K and Fujii Y: microRNA expression profile in undifferentiated gastric cancer. Int J Oncol 34: 537-542, 2009.

24. Chen G, Tang Y, Wu JH and Liu FH: Role of microRNAs in diagnosis and treatment of the pathogenesis of gastric cancer. Int J Clin Exp Med 7: 5947-5957, 2014.

25. Jiang J, Zheng X, Xu X, Zhou Q, Yan H, Zhang X, Lu B, Wu C and Ju J: Prognostic significance of miR-181b and miR-21 in gastric cancer patients treated with S-1/Oxaliplatin or Doxifluridine/ oxaliplatin. PLoS One 6: e23271, 2011.

26. Guo JX, Tao QS, Lou PR, Chen XC, Chen J and Yuan GB: miR-181b as a potential molecular target for anticancer therapy of gastric neoplasms. Asian Pac J Cancer Prev 13: 2263-2267, 2012.

27. Chen L, Yang Q, Kong W-Q, Liu T, Liu M, Li X and Tang H: MicroRNA-181b targets cAMP responsive element binding protein 1 in gastric adenocarcinomas. IUBMB Life 64: 628-635, 2012.

28. Xu YJ and Fan Y: MiR-215/192 participates in gastric cancer progression. Clin Transl Oncol 17: 34-40, 2015.

29. Chen Q, Ge X, Zhang Y, Xia H, Yuan D, Tang Q, Chen L, Pang X, Leng W and Bi F: Plasma miR-122 and miR-192 as potential novel biomarkers for the early detection of distant metastasis of gastric cancer. Oncol Rep 31: 1863-1870, 2014.

30. Sun T, Yang M, Kantoff P and Lee GS: Role of microRNA221/-222 in cancer development and progression. Cell Cycle 8: 2315-2316, 2009

31. Wang J, Liu S, Sun GP, Wang F, Zou YF, Jiao Y, Ning J and $\mathrm{Xu}$ J: Prognostic significance of microRNA-221/222 expression in cancers: Evidence from 1,204 subjects. Int J Biol Markers 29: e129-e141, 2014.

32. Liu K, Li G, Fan C, Diao Y, Wu B and Li J: Increased expression of MicroRNA-221 in gastric cancer and its clinical significance. J Int Med Res 40: 467-474, 2012.

33. Chun-Zhi Z, Lei H, An-Ling Z, Yan-Chao F, Xiao Y, Guang-Xiu W, Zhi-Fan J, Pei-Yu P, Qing-Yu Z and Chun-Sheng K: MicroRNA-221 and microRNA-222 regulate gastric carcinoma cell proliferation and radioresistance by targeting PTEN. BMC Cancer 10: 367, 2010.

34. Mao S, He N, Xin L, Zeng F and Cao J: Effect of antisense miR-224 on gastric cancer cell proliferation and apoptosis. Zhonghua Zhong Liu Za Zhi 36: 92-96, 2014 (In Chinese).

35. Liu H, Li P, Li B, Sun P, Zhang J, Wang B and Jia B: RKIP suppresses gastric cancer cell proliferation and invasion and enhances apoptosis regulated by microRNA-224. Tumour Biol 35: 10095-10103, 2014.

36. Tao K, Yang J, Guo Z, Hu Y, Sheng H, Gao $\mathrm{H}$ and $\mathrm{Yu} \mathrm{H}$ : Prognostic value of miR-221-3p, miR-342-3p and miR-491-5p expression in colon cancer. Am J Transl Res 6: 391-401, 2014.

37. Kim CH, Kim HK, Rettig RL, Kim J, Lee ET, Aprelikova O, Choi IJ, Munroe DJ and Green JE: miRNA signature associated with outcome of gastric cancer patients following chemotherapy. BMC Med Genomics 4: 79, 2011.

38. Liu Y, Xing R, Zhang X, Dong W, Zhang J, Yan Z, Li W, Cui J and $\mathrm{Lu} \mathrm{Y:} \mathrm{miR-375} \mathrm{targets} \mathrm{the} \mathrm{p53} \mathrm{gene} \mathrm{to} \mathrm{regulate} \mathrm{cellular}$ response to ionizing radiation and etoposide in gastric cancer cells. DNA Repair (Amst) 12: 741-750, 2013.

39. Shen Q, Yao Q, Sun J, Feng L, Lu H, Ma Y, Liu L, Wang F, Li J, Yue Y, et al: Downregulation of histone deacetylase 1 by microRNA-520h contributes to the chemotherapeutic effect of doxorubicin. FEBS Lett 588: 184-191, 2014.

40. Zhao Z, Zhang L, Yao Q and Tao Z: miR-15b regulates cisplatin resistance and metastasis by targeting PEBP4 in human lung adenocarcinoma cells. Cancer Gene Ther 22: 108-114, 2015. 
41. Xia L, Zhang D, Du R, Pan Y, Zhao L, Sun S, Hong L, Liu J and Fan D: miR-15b and miR-16 modulate multidrug resistance by targeting BCL2 in human gastric cancer cells. Int J Cancer 123 $372-379,2008$

42. Kim CH, Kim HK, Rettig RL, Kim J, Lee ET, Aprelikova O, Choi IJ, Munroe DJ and Green JE: miRNA signature associated with outcome of gastric cancer patients following chemotherapy. BMC Med Genomics 4: 79, 2011.

43. Li L, Zhou L, Li Y, Lin S and Tomuleasa C: MicroRNA-21 stimulates gastric cancer growth and invasion by inhibiting the tumor suppressor effects of programmed cell death protein 4 and phosphatase and tensin homolog. J BUON 19: 228-236, 2014.

44. Yang SM, Huang C, Li XF, Yu MZ, He Y and Li J: miR-21 confers cisplatin resistance in gastric cancer cells by regulating PTEN. Toxicology 306: 162-168, 2013.

45. Liu T, Tang H, Lang Y, Liu M and Li X: MicroRNA-27a functions as an oncogene in gastric adenocarcinoma by targeting prohibitin. Cancer Lett 273: 233-242, 2009.

46. Huang D, Wang H, Liu R, Li H, Ge S, Bai M, Deng T, Yao G and Ba Y: miRNA27a is a biomarker for predicting chemosensitivity and prognosis in metastatic or recurrent gastric cancer. J Cell Biochem 115: 549-556, 2014.

47. Peng Y, Guo JJ, Liu YM and Wu XL: MicroRNA-34A inhibits the growth, invasion and metastasis of gastric cancer by targeting PDGFR and MET expression. Biosci Rep 34: 34, 2014.

48. Cao W, Yang W, Fan R, Li H, Jiang J, Geng M, Jin Y and Wu Y: miR-34a regulates cisplatin-induce gastric cancer cell death by modulating PI3K/AKT/survivin pathway. Tumour Biol 35: $1287-1295,2014$.

49. Molina-Pinelo S, Carnero A, Rivera F, Estevez-Garcia P, Bozada JM, Limon ML, Benavent M, Gomez J, Pastor MD, Chaves M, et al: MiR-107 and miR-99a-3p predict chemotherapy response in patients with advanced colorectal cancer. BMC Cancer 14: 656, 2014

50. Wang HJ, Ruan HJ, He XJ, Ma YY, Jiang XT, Xia YJ, Ye ZY and Tao HQ: MicroRNA-101 is down-regulated in gastric cancer and involved in cell migration and invasion. Eur J Cancer 46: 2295-2303, 2010.

51. Bu Q, Fang Y, Cao Y, Chen Q and Liu Y: Enforced expression of miR-101 enhances cisplatin sensitivity in human bladder cancer cells by modulating the cyclooxygenase- 2 pathway. Mol Med Rep 10: 2203-2209, 2014

52. Fang Y, Shen H, Li H, Cao Y, Qin R, Long L, Zhu X, Xie C and $\mathrm{Xu}$ W: miR-106a confers cisplatin resistance by regulating PTEN/ Akt pathway in gastric cancer cells. Acta Biochim Biophys Sin (Shanghai) 45: 963-972, 2013.

53. Zhang Y, Lu Q and Cai X: MicroRNA-106a induces multidrug resistance in gastric cancer by targeting RUNX3. FEBS Lett 587: 3069-3075, 2013.

54. Wang S, Lv C, Jin H, Xu M, Kang M, Chu H, Tong N, Wu D, Zhu $\mathrm{H}$, Gong W, et al: A common genetic variation in the promoter of miR-107 is associated with gastric adenocarcinoma susceptibility and survival. Mutat Res 769: 35-41, 2014.

55. Zhang Z, Zhang L, Yin ZY, Fan XL, Hu B, Wang LQ and Zhang D: miR-107 regulates cisplatin chemosensitivity of A549 non-small cell lung cancer cell line by targeting cyclin dependent kinase 8. Int J Clin Exp Pathol 7: 7236-7241, 2014.

56. Zuo QF, Zhang R, Li BS, Zhao YL, Zhuang Y, Yu T, Gong L, Li S, Xiao B and Zou QM: MicroRNA-141 inhibits tumor growth and metastasis in gastric cancer by directly targeting transcriptional co-activator with PDZ-binding motif, TAZ. Cell Death Dis 6: e1623, 2015

57. Zhou X, Su J, Zhu L and Zhang G: Helicobacter pylori modulates cisplatin sensitivity in gastric cancer by down-regulating miR-141 expression. Helicobacter 19: 174-181, 2014

58. Wu XL, Cheng B, Li PY, Huang HJ, Zhao Q, Dan ZL, Tian DA and Zhang P: MicroRNA-143 suppresses gastric cancer cell growth and induces apoptosis by targeting COX-2. World J Gastroenterol 19: 7758-7765, 2013.

59. Zhuang M, Shi Q, Zhang X, Ding Y, Shan L, Shan X, Qian J, Zhou X, Huang Z, Zhu W, et al: Involvement of miR-143 in cisplatin resistance of gastric cancer cells via targeting IGF1R and BCL2. Tumour Biol 36: 2737-2745, 2015.

60. Gao P, Xing AY, Zhou GY, Zhang TG, Zhang JP, Gao C, Li H and Shi DB: The molecular mechanism of microRNA-145 to suppress invasion-metastasis cascade in gastric cancer. Oncogene 32 491-501, 2013.
61. Liu RL, Dong Y, Deng YZ, Wang WJ and Li WD: Tumor suppressor miR-145 reverses drug resistance by directly targeting DNA damage-related gene RAD18 in colorectal cancer. Tumour Biol 36: 5011-5019, 2015.

62. Lei Y, Hu X, Li B, Peng M, Tong S, Zu X, Wang Z, Qi L and Chen M: miR-150 modulates cisplatin chemosensitivity and invasiveness of muscle-invasive bladder cancer cells via targeting PDCD4 in vitro. Med Sci Monit 20: 1850-1857, 2014.

63. Boni V, Bitarte N, Cristobal I, Zarate R, Rodriguez J, Maiello E, Garcia-Foncillas J and Bandres E: miR-192/miR-215 influence 5-fluorouracil resistance through cell cycle-mediated mechanisms complementary to its post-transcriptional thymidilate synthase regulation. Mol Cancer Ther 9: 2265-2275, 2010.

64. Wang XW, Wu Y, Wang D and Qin ZF: MicroRNA network analysis identifies key microRNAs and genes associated with precancerous lesions of gastric cancer. Genet Mol Res 13: 8695-8703, 2014

65. Deng H, Lv L, Li Y, Zhang C, Meng F, Pu Y, Xiao J, Qian L, Zhao W, Liu Q, et al: miR-193a-3p regulates the multi-drug resistance of bladder cancer by targeting the LOXL4 gene and the oxidative stress pathway. Mol Cancer 13: 234, 2014.

66. Zhao Y, Li C, Wang M, Su L, Qu Y, Li J, Yu B, Yan M, Yu Y, Liu B, et al: Decrease of miR-202-3p expression, a novel tumor suppressor, in gastric cancer. PLoS One 8: e69756, 2013.

67. Ren J, Huang HJ, Gong Y, Yue S, Tang LM and Cheng SY: MicroRNA-206 suppresses gastric cancer cell growth and metastasis. Cell Biosci 4: 26, 2014.

68. Zheng Z, Yan D, Chen X, Huang H, Chen K, Li G, Zhou L, Zheng D, Tu L and Dong XD: MicroRNA-206: Effective inhibition of gastric cancer progression through the c-Met pathway. PLoS One 10: e0128751, 2015.

69. Yan W, Wang S, Sun Z, Lin Y, Sun S, Chen J and Chen W: Identification of microRNAs as potential biomarker for gastric cancer by system biological analysis. BioMed Res Int 2014: 901428,2014

70. Maftouh M, Avan A, Funel N, Frampton AE, Fiuji H, Pelliccioni S, Castellano L, Galla V, Peters GJ and Giovannetti E: miR-211 modulates gemcitabine activity through downregulation of ribonucleotide reductase and inhibits the invasive behavior of pancreatic cancer cells. Nucleosides Nucleotides Nucleic Acids 33: 384-393, 2014.

71. Tie J, Pan Y, Zhao L, Wu K, Liu J, Sun S, Guo X, Wang B, Gang Y, Zhang Y, et al: MiR-218 inhibits invasion and metastasis of gastric cancer by targeting the Robol receptor. PLoS Genet 6: e1000879, 2010.

72. He X, Xiao X, Dong L, Wan N, Zhou Z, Deng H and Zhang X: MiR-218 regulates cisplatin chemosensitivity in breast cancer by targeting BRCA1. Tumour Biol 36: 2065-2075, 2015.

73. Wang H, Zhu LJ, Yang YC, Wang ZX and Wang R: MiR-224 promotes the chemoresistance of human lung adenocarcinoma cells to cisplatin via regulating $\mathrm{G}_{1} / \mathrm{S}$ transition and apoptosis by

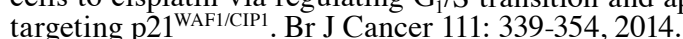

74. Amankwatia EB, Chakravarty P, Carey FA, Weidlich S, Steele RJ, Munro AJ, Wolf CR and Smith G: MicroRNA-224 is associated with colorectal cancer progression and response to 5-fluorouracil-based chemotherapy by KRAS-dependent and -independent mechanisms. Br J Cancer 112: 1480-1490, 2015

75. Zhou C, Li X, Zhang X, Liu X, Tan Z, Yang C and Zhang J: microRNA-372 maintains oncogene characteristics by targeting TNFAIP1 and affects $N F-\kappa \mathrm{B}$ signaling in human gastric carcinoma cells. Int J Oncol 42: 635-642, 2013.

76. Xu Y, Jin J, Liu Y, Huang Z, Deng Y, You T, Zhou T, Si J and Zhuo W: Snail-regulated MiR-375 inhibits migration and invasion of gastric cancer cells by targeting JAK2. PLoS One 9: e99516, 2014

77. Berghmans T, Ameye L, Willems L, Paesmans M, Mascaux C, Lafitte JJ, Meert AP, Scherpereel A, Cortot AB, Cstoth I, et al; European Lung Cancer Working Party: Identification of microRNA-based signatures for response and survival for non-small cell lung cancer treated with cisplatin-vinorelbine A ELCWP prospective study. Lung Cancer 82: 340-345, 2013.

78. Yoon S, Han E, Choi YC, Kee H, Jeong Y, Yoon J and Baek K: Inhibition of cell proliferation and migration by miR-509-3p that targets CDK2, Rac1, and PIK3C2A. Mol Cells 37: 314-321, 2014.

79. Yao Y, Suo AL, Li ZF, Liu LY, Tian T, Ni L, Zhang WG, Nan KJ, Song TS and Huang C: MicroRNA profiling of human gastric cancer. Mol Med Rep 2: 963-970, 2009.

80. To KKW, Robey RW, Knutsen T, Zhan Z, Ried T and Bates SE: Escape from hsa-miR-519c enables drug-resistant cells to maintain high expression of ABCG2. Mol Cancer Ther 8: 2959-2968, 2009. 